\title{
Isolation and characterization of novel microsatellite loci in Nibea albiflora
}

\author{
D.D. Xu, B. Lou, S.L. Li, Y.R. Zhang, J. Xin and W. Zhan
}

Marine Fishery Institute of Zhejiang Province,

Key Laboratory of Mariculture and Enhancement of Zhejiang Province, Zhoushan, Zhejiang Province, China

Corresponding author: B. Lou

E-mail: loubao6577@163.com

Genet. Mol. Res. 12 (4): 6156-6159 (2013)

Received November 4, 2012

Accepted March 30, 2013

Published December 4, 2013

DOI http://dx.doi.org/10.4238/2013.December.4.1

\begin{abstract}
Eleven novel microsatellite loci were isolated from a (CA) ${ }_{10}$-enriched genomic DNA library of Nibea albiflora. The characteristics of these microsatellites were determined in a sample of $48 \mathrm{~N}$. albiflora individuals. The number of alleles at the 11 microsatellite loci ranged from 5 to 25 , with an average of 13.5 per locus. The observed and expected heterozygosities varied from 0.583 to 0.917 and from 0.568 to 0.964 , respectively. Eight of the 11 microsatellite loci conformed to the Hardy-Weinberg equilibrium. No significant linkage disequilibrium was found among all 11 loci. These polymorphic microsatellites will be useful for population genetic analyses of $N$. albiflora.
\end{abstract}

Key words: Nibea albiflora; Microsatellite; Polymorphism 


\section{INTRODUCTION}

Nibea albiflora is a coastal fish belonging to the family Sciaenidae in the order Perciformes (Zhu et al., 1963). This species is mainly distributed from the South China Sea to the coastal waters of Japan and Korea (Takita, 1974). N. albiflora is an economically important fisheries and aquaculture species in China. However, in recent years, the wild resource of $N$. albiflora has decreased sharply as a result of overfishing and water pollution. For developing rational strategies to protect the genetic resources and to utilize the valuable resources sustainably, it is critical to analyze the genetic variation in $N$. albiflora to reveal its genetic background. To date, studies on the population structure of $N$. albiflora have only been carried out using amplified fragment length polymorphism and mitochondrial DNA analyses (Han et al., 2006, 2008).

Microsatellite markers have been widely used in genetics and ecology studies, such as on genetic identification, parentage, and population variability, and are considered one of the best genetic markers (Liu and Cordes, 2004). Previously, 29 microsatellite markers were developed in N. albiflora (Xing et al., 2009; Ma et al., 2011). However, these loci were not enough for developing a large-scale population genetic study on $N$. albiflora. To find more species-specific markers with high polymorphism, herein, we constructed DNA-enriched libraries for the dinucleotide microsatellite (CA repeats), and 11 novel polymorphic microsatellite loci were isolated from it.

\section{MATERIAL AND METHODS}

Genomic DNA was extracted from the fin clips of one individual fish by using a previously described method (Yue and Orban, 2005). Microsatellite loci were isolated and cloned according to the protocol described by Yue et al. (2000). A partial genomic DNA library enriched for CA repeats was constructed using the enrichment technique. DNA was digested with RsaI, and the resulting fragments were separated on a $1.0 \%$ agarose gel. Fragments of 250 to $1000 \mathrm{bp}$ were excised, purified, and ligated with 20 pmol 21- and 25-mer oligo adaptors (Fischer and Bachmann, 1998). The CA repeats were enriched from the ligated DNA using biotinylated probes $(\mathrm{CA})_{10}$ and streptavidin-coated magnetic beads (Dynal). The magnetic beads-captured DNA containing the microsatellites were eluted. The eluted fragments were amplified using 21-mer as primers and then ligated to pGEM-T-vector (Promega) according to the manufacturer protocol. The ligation products were transformed into XL1-Blue competent cells (Strategene). Colony polymerase chain reaction (PCR) products were sequenced in both the $5^{\prime}$ and $3^{\prime}$ directions on an ABI3100 sequencer (Applied Biosystems) using a BigDye sequencing kit (Applied Biosystems). Primers were designed for 11 microsatellites in the regions flanking the repeats using the software Primer 3.0 (Rozen and Skaletsky, 2000). One of each primer pair was labeled with FAM, NED, PET, or VIC fluorescent dye.

To characterize the isolated microsatellites, we genotyped 48 individual fish collected from the waters of Zhoushan Coast $\left(122^{\circ} 30^{\prime} \mathrm{N}, 30^{\circ} 08^{\prime} \mathrm{E}\right)$ in the East China Sea. PCR amplification was carried out in a $25-\mu \mathrm{L}$ reaction mixture including $10 \mathrm{pmol}$ each primer set; $100 \mu \mathrm{M}$ dNTPs; $10 \mathrm{mM}$ Tris-HCl, $\mathrm{pH} 8.3 ; 50 \mathrm{mM} \mathrm{KCl} ; 1.5 \mathrm{mM} \mathrm{MgCl}$; $1 \mathrm{U} \mathrm{Taq}$ 
polymerase (TaKaRa); and 40 ng template DNA. The PCR profile consisted of an initial denaturation at $94^{\circ} \mathrm{C}$ for $5 \mathrm{~min}$; followed by 35 cycles of $94^{\circ} \mathrm{C}$ for $30 \mathrm{~s}$, annealing temperature for $45 \mathrm{~s}$, and $72^{\circ} \mathrm{C}$ for $1 \mathrm{~min}$; and finally one cycle of $72^{\circ} \mathrm{C}$ for $7 \mathrm{~min}$. Following amplification, the PCR products were mixed with $5 \mu \mathrm{L}$ sequencing dye and heated for 5 min at $95^{\circ} \mathrm{C}$. The PCR products were separated by electrophoresis on an ABI3730xl DNA sequencer (Applied Biosystems). The number of alleles and observed $\left(H_{\mathrm{O}}\right)$ and expected $\left(H_{\mathrm{E}}\right)$ heterozygosities were calculated using the software Arlequin 3.01 (Excoffier et al., 2005). Conformance of genotypic proportions to Hardy-Weinberg equilibrium was tested using exact tests in the software Genepop 4.1 (Raymond and Rousset, 1995). Probability values were determined based on 10,000 dememorizations, 1000 batches, and 10,000 iterations per batch.

\section{RESULTS AND DISCUSSION}

The characteristics of the 11 primer pairs that achieved successful amplification of a scorable PCR product are present in Table 1. The observed numbers of alleles ranged from 5 to 25 , with an average of 13.5 alleles per locus. The $H_{\mathrm{O}}$ values ranged from 0.583 to 0.917 and the $H_{\mathrm{E}}$ values from 0.568 to 0.964 . The average $H_{\mathrm{O}}$ and $H_{\mathrm{E}}$ values were 0.754 and 0.832 , respectively. Significant deviations from Hardy-Weinberg equilibrium were found at three microsatellite loci (Nibea08, Nibea10, and Nibea11). No evidence of linkage disequilibrium was observed by the linkage disequilibrium test for each pair of loci. In conclusion, these 11 microsatellite markers will be useful for the development of parentage, population genetics, and genome mapping studies in N. albiflora.

\begin{tabular}{|c|c|c|c|c|c|c|c|c|}
\hline Locus & Repeat motif & Primer sequence 5'-3' (label) & $\mathrm{Ta}\left({ }^{\circ} \mathrm{C}\right)$ & $N_{\mathrm{A}}$ & Allele-size range & $H_{\mathrm{O}}$ & $H_{\mathrm{E}}$ & $P_{\mathrm{HW}}$ \\
\hline Nibea01 & $(\mathrm{TG})_{10}$ & $\begin{array}{l}\text { F: CTTGGTTTTAGGTATCCAGGCTCT (FAM) } \\
\text { R: TGCCCACTCACCTGTGTCATT }\end{array}$ & 55 & 10 & $212-244$ & 0.708 & 0.757 & 0.437 \\
\hline Nibea02 & $(\mathrm{CT})_{25}$ & $\begin{array}{l}\text { F: ACAGAACACATCCAAACAAAGG(VIC) } \\
\text { R: AACCAAAAGAAAGGAGCGAC }\end{array}$ & 51 & 25 & $207-254$ & 0.917 & 0.940 & 0.338 \\
\hline Nibea03 & $(\mathrm{GT})_{9}$ & $\begin{array}{l}\text { F: TGTCACACGCAGGGTAATG(NED) } \\
\text { R: TCAGGCAGCCGCAGTAT }\end{array}$ & 52 & 9 & $157-215$ & 0.667 & 0.817 & 0.055 \\
\hline Nibea04 & $(\mathrm{GA})_{15}$ & $\begin{array}{l}\text { F: AAGACGGTATGCCAGGGTT(PET) } \\
\text { R: GTTCAGGAGCAAAAAAATAAGAGA }\end{array}$ & 51 & 20 & 228-306 & 0.833 & 0.901 & 0.069 \\
\hline Nibea05 & $(\mathrm{CT})_{10}$ & $\begin{array}{l}\text { F: CAAAGGTTAGCCCCAAATCTG(VIC) } \\
\text { R: CGCACAATAAGCAATCACATAC }\end{array}$ & 55 & 6 & 201-219 & 0.750 & 0.716 & 0.910 \\
\hline Nibea06 & $(\mathrm{CA})_{10}$ & $\begin{array}{l}\text { F: GCACACCTGACCGTGAACA(NED) } \\
\text { R: GAAGAGAACAACCTGGTAATGAACT }\end{array}$ & 54 & 15 & $180-217$ & 0.875 & 0.899 & 0.139 \\
\hline Nibea07 & $(\mathrm{AG})_{13}$ & $\begin{array}{l}\text { F: GAAGAAGTGAGAGAAAAGGGG(PET) } \\
\text { R: ATTATGTGAAAGTGCTGCGAG }\end{array}$ & 53 & 8 & $191-207$ & 0.833 & 0.840 & 0.926 \\
\hline Nibea08 & $(\mathrm{GACA})_{23}$ & $\begin{array}{l}\text { F: AAATGTTTGGCTGTGCTATGA(FAM) } \\
\text { R: ATTGTGTGGCTGTTTTGTGTTA }\end{array}$ & 51 & 22 & 236-306 & 0.667 & 0.964 & 0.000 \\
\hline Nibea09 & $(\mathrm{TC})_{26}$ & $\begin{array}{l}\text { F: TGCCTTTTGGAAATCAGCCT (VIC) } \\
\text { R: ACATCTCCCTAACAGTCGCATAATA }\end{array}$ & 51 & 18 & $262-303$ & 0.875 & 0.936 & 0.724 \\
\hline Nibea10 & $(\mathrm{AC})_{11}$ & $\begin{array}{l}\text { F: TCTTTGCTTTCTCTCGGTGA (NED) } \\
\text { R: GGATGTGGTTTTGGTGTGTC }\end{array}$ & 51 & 10 & $191-203$ & 0.583 & 0.816 & 0.003 \\
\hline Nibea11 & $(\mathrm{TG})_{10}$ & $\begin{array}{l}\text { F: GAGTGTCCTTGTGTGTTTATTCATCTG(PET) } \\
\text { R: AGCACCTGCCGCTCTCTGTA }\end{array}$ & 55 & 5 & $113-197$ & 0.583 & 0.568 & 0.042 \\
\hline
\end{tabular}

$\mathrm{Ta}=$ annealing temperature; $N_{\mathrm{A}}=$ number of alleles; $H_{\mathrm{O}}=$ observed heterozygosity; $H_{\mathrm{E}}=$ expected heterozygosity; $P_{\mathrm{HW}}=$ probability of departure from Hardy-Weinberg equilibrium. 


\section{ACKNOWLEDGMENTS}

Research supported by grants from the the National "863" High Technology Research Foundation of China (\#2012AA10A413-5) and Project of Zhejiang Province of China (Projects \#2009C12081, \#2010F20006, and \#2012C12907-8).

\section{REFERENCES}

Excoffier L, Laval G and Schneider S (2005). Arlequin (version 3.0): an integrated software package for population genetics data analysis. Evol. Bioinform. Online 1: 47-50.

Fischer D and Bachmann K (1998). Microsatellite enrichment in organisms with large genomes (Allium cepa L.). Biotechniques 24: 796-800, 802.

Han ZQ, Gao TX, Wang ZY, Zhuang ZM, et al. (2006). Analysis of genetic diversity of Nibea albiflora by AFLP markers. J. Fish. China 5: 646-640.

Han ZQ, Gao TX, Yanagimoto T and Sakurai Y (2008). Genetic population structure of Nibea albiflora in Yellow Sea and East China Sea. Fish. Sci. 74: 544-552.

Liu ZJ and Cordes JF (2004). DNA marker technologies and their applications in aquaculture genetics. Aquaculture 238: $1-37$.

Ma C, Ma H, Ma L, Jiang K, et al. (2011). Isolation and characterization of 16 polymorphic microsatellite markers from Nibea albiflora. Fish. Sci. 77: 707-711.

Raymond M and Rousset F (1995). GENEPOP (version 1.2): population genetics software for exact tests and ecumenicism. J. Hered. 86: 248-249.

Rozen S and Skaletsky H (2000). Primer3 on the WWW for general users and for biologist programmers. Methods Mol. Biol. 132: 365-386.

Takita T (1974). Studies on the early life history of Nibea albiflora (Richardson) in Ariake Sound. Bull. Fac. Fish. Nagasaki Univ. 38: 1-55.

Xing S, Shao C, Liao X, Tian Y, et al. (2009). Isolation and characterization of polymorphic microsatellite loci from a dinucleotide-enriched genomic library of spotted maigre (Nibea albiflora). Conserv. Genet. 10: 789-791.

Yue GH, Chen F and Orban L (2000). Rapid isolation and characterization of microsatellites from the genome of Asian arowana (Scleropages formosus, Osteoglossidae, Pisces). Mol. Ecol. 9: 1007-1009.

Yue GH and Orban L (2005). A simple and affordable method for high-throughput DNA extraction from animal tissues for polymerase chain reaction. Electrophoresis 26: 3081-3083.

Zhu YD, Luo YL and Wu HL (1963). A Study on the Classification of the Sciaenoid Fishes of China, with Description of New Genera and Species. Shanghai Scientific and Technical Press, Shangai. 